Review

\title{
Chinese star anise and anise, magic herbs in traditional Chinese medicine and modern pharmaceutical science
}

\author{
Mohamad Hesam Shahrajabian ${ }^{1,2}$, Wenli Sun ${ }^{1,2}$ and Qi Cheng ${ }^{1,2^{*}}$ \\ ${ }^{1}$ Biotechnology Research Institute, Chinese Academy of Agricultural Sciences, Beijing 100081, China \\ ${ }^{2}$ Nitrogen Fixation Laboratory, Qi Institute, Building C4, No.555 Chuangye Road, Jiaxing 314000, Zhejiang, \\ China
}

*Corresponding author: Qi Cheng, Biotechnology Research Institute, Chinese Academy of Agricultural Sciences, Beijing 100081, China. E-mail: chengqi@ caas.cn

Received: 05 August 2019/Accepted: 08 September 2019/ Published: 30 September 2019

\begin{abstract}
Star anise (Illicium verum Hook. f.) is an important herb in traditional Chinese medicine as well as traditional Asian medicine. The fruit is aromatic and has a strong, pungent and mildly sweet taste. Star anise is one of the many species that contain bioactive compounds as well as a number of phenolic and flavonoid compounds, having antioxidant, preservative and antimicrobial properties. All relevant papers in the English language from researchers of different countries were collected. The keywords of Chinese star anise, anise, traditional Chinese medicine and modern pharmaceutical science were searched in Google Scholar, Scopus, Research Gate and PubMed. Its seeds are good source of minerals like calcium, iron, copper, potassium, manganese, zinc, and magnesium. The essential oil of Chinese star anise contains anethole which has shown several functional properties including antimicrobial, antioxidant, hypoglycemic, hypolipidemic and oestrogenic properties. Due to all positive characteristics, such as antidiabetic, hypolipidemic, antioxidant activities, anticancer and antimicrobial properties, both seeds and essential oils of anise is promising for safe use as super food supplements and raw constituents in the both pharmaceutical and food industries. Anise seed oil contains anethol, estragole, eugenol, pseudisoeugenol, methyl chavicol and anisaldehyde, coumarins, scopoleting, umbelliferon, estrols, terpene hydrocarbons, and polyacetylenes as the major compounds. The plant oil has both pharmacological and clinical effects. The pharmacological effects consist of antimicrobial, hepatopreotective, anticonvulsant, anti-inflammatory, antispasmodic, bronchodilator, estrogenic, expectorant and insecticidal effects, and clinical effects such as nausea, constipation, menopausal period, virus, diabetes, obesity and sedative action. Combined with a nutritious diet, other traditional Chinese and Asian medicine, Chinese star anise and ansie seed may improve various aspects of health. More clinical studies are necessary to uncover the numerous substances and their effects in ginseng that contribute to public health.
\end{abstract}

Keywords: Chinese star anise; Anise, traditional Chinese medicine; modern pharmaceutical science

\section{Introduction}

The ancient Chinese have identified 11,146 medicinal species from 383 families, and more than 400 of which widely used through the world, which means that China is the native home to a greater diversity of the world's herbal plants than any other regions in the world. The herbal apothecary in China grew from hundred herbs recorded in the oldest version of Shen Nong Ben Cao Jing by Tao Hongjing to almost 1,900 substances in Li Shizehen's monumental encyclopedic research, the Bencao Gangmu published a few years after his death in the late Ming dynasty, $1596 \mathrm{AD}$. TCM which is one of the most important part of the health care system in most Asian countries, relies on natural products and had been playing a very significant role in health protecting and disease control for many years. Traditional Chinese medicine plays an important role in sustainable agriculture and food systems, it also offers a holistic approach to prevent diseases while making appropriate use of organic and herbal products especially growth by small-scale family farmers. The aim of this review is survey on two 
important crop in traditional Chinese medicine, namely Chinese star anise and anise and their potential health benefits and pharmacological usages of them.

\section{Chinese star anise}

\subsection{Botany and plant description of Chinese star anise}

Traditional Chinese medicines consider as both medicine and food item, because most of Chinese medicine are used as pigments and flavors in the preparation of Chinese food items (Yang et al., 2010; Soleymani and Shahrajabian, 2012; Ogbaji et al., 2018; Shahrajabian et al., 2018; Soleymani et al., 2018; Shahrajabian et al., 2019a,b,c,d,e,f). Star anise (I. verum Hook. f.) is a medium-sized evergreen tree which is native to southwest of China; and also widely cultivated in the subtropical and tropical areas of Asia (De et al., 2001; Chouksey et al., 2010; Benmalek et al., 2013; Li et al., 2013; Elmasry et al., 2018). Common name of I. verum has many synonyms in different areas: Chinese star anise or Bajiaohuixiang in China; Anis de la Chine, Anise etoile or Badiane in France; Dai-uikyo or Hakkaku-uikyo in Japan; Sternanis in Germany; Anice stellato in Italy; Sonf or Anasphal in India; Anis estrellado in Spain; Bunga lawing in Indonesia and Malaysia (Wang et al., 2011). De et al. (2001) reported that star anise is extensively cultivated in a limited area with particular ecological factors in Kwangsi in South East China and Tonkin in Indo-China. Chinese star anise is considered as one of the flavors used in China five spices (Thuat and Ngoc, 2010; Ibrahim et al., 2016; Acimovic et al., 2017). In traditional Chinese medicine, it is called as warming yang and dispelling cold, and regulating the flow of Qi to relieve pain or common cold (Wang et al., 2011). It has been also reported that its crude fruits and its powders were used in traditional teas to treat nervousness and sleeplessness and also as a sedative (Wang et al., 2011). Dried ripe, star anise fruit and seed are used as important spice in Asian cooking especially in Chinese, Vietnamese and Indian cuisines. Vietnam produces more than $5000 \mathrm{t}$ of star anise seeds per annum; and it is estimated that the combined production of China and Vietnam is more than 25,000 $t$ per annum. Moreover, 200-250 $t$ of essential oil are shipped to France and the Czech Republic. In China, which is the largest supplier of star anise to the world market, Vietnamese star anise is blended and then exported to France. In France, it is used as a raw material in the production of alcoholic beverages (FAO, 1993). Wang et al. (2011) found that star anise (Illiciaceae, Illicium verum Hook. f.) has long been used in traditional Chinese medicine and the food industry with the effects of dispelling cold, regulating the flow of Qi, and relieving pain. Chinese star anise together with the morphological similar Japanese star anise together with the morphologically similar Japanese star anise (Illicium anisatum), is also used for decoration purposes (Shen et al., 2012). Illicium verum Hook. f. mainly grows in the provinces of Guangxi, Guangdong and Yunnan, covered nearly $80 \%$ in the world (Yan et al., 2002). This plant also has been reported to possess anti-bacterial, anti-cancer and of course anti-inflammatory characteristics (De et al., 2002; Itoigawa et al., 2004; Yang et al., 2010). Kang et al. (2013) noted that Chinese anise star can alleviate inflammatory responses and is a common flavor in medicinal tea, cough mixtures and pastilles. Star anise is classified in the division Magnoliohpyta, class Magnoliopsida, sub-class Magnoliidae, order Austrobaileyales, family Illiciaceae. De et al. (2001) mentioned that among all Illicium species present throught the world, such as Illicium dunnianum, Illicium griffithii, Illicium verym and Illicium anisatum, just Illicium verum Hooker anisatum is non-poisonous and has been used in culinary preparation and also as famous traditional medicine. Vermaak et al. (2013) mentioned that dried fruit of Chinese star anise is used as a remedy to treat infant colic. Japanese star anise, Illicium anisatum (Schisandraceae) is an evergreen broad-leaved tree or shrub that exhibits ballochory (Romanov et al., 2013). The plant is widely distributed in the central and southern parts of the Japanese archipelago (Yoshikawa et al., 2018). Japanese star anise looks very similar to Chinese star anise in its dried form but that is where the similarity ends. The Japanese star anise is extremely toxic and is not edible in any form (Vermaak et al., 2013; Yoshikawa et al., 2018). Recently concern has been raised regarding adulteration of Chinese star anise with Japanese star anise (Shen et al., 2012; Scharge et al., 2013). Only Japanese star anise fruits contain the neurotoxic anisatin, which is a strong non-competitive antagonist of the $\mathrm{GABA}_{\mathrm{A}}$-receptor (Kudo et al., 1981). Nakazawa et al. (1959) also found that the fruit is also most toxic, followed by the seed, root, leaf and bark. It is very difficult to detect fragments of Japanese star anise fruit in powdered Chinese Star Anise fruit (Techen et al., 2009). Various methods have been used to identify and distinguish between them, such as morphological, chemical analysis by fluorescent microscopy, gas chromatography and an HPLC/ESI-MS/MS method (Joshi et al., 2005; Lederer et al., 2006). Howes et al. (2009) explained that the volatiles desorbed from the pericarps of the toxic I. anisatum (Japanese star anise) were characterized by the presence of asaricin, methoxyeugenol, and two other eugenol derivatives, and none of which were detected in any other species examined. Star anise is a medium sized tree, 8-15 $\mathrm{m}$ tall and $30 \mathrm{~cm}$ depth, with the bark which is white to bright grey. Furthermore, its leaves are 6-12 cm long, alternate, simple, leathery, entire, glabrous, shining, usually crowded in bundles at the end of the branches; it also has large 
flower, bisexual, $1-1.5 \mathrm{~cm}$ in diameter, white pink to red or greenish yellow, axillary and solitary (Vecchio $e t$ al., 2016). Fruit is capsule like, aggregate is star shapes; each arm is seed pod. In China, star anise is frequently used as spice in Chinese cuisine. Its fruit has an agreeable, aromatic, sweet taste and a pleasant fragrance resembling anise (De et al., 2001). Guangxi followed by Guangdong, Yunnan, and Fujian are the original and main production regions of star anise in China, accounting for more than $85 \%$ of the total average of star anise in China (Ma et al., 2011). Prajapati et al., (2007) and Fritz et al. (2008) reported that fruits are picked before they ripe and dried, and seeds are shiny brown or reddish with high oil content. Vecchio et al. (2016) also noted that flowers bloom from March to May, and the fruits ripe from September to October. Anethole of star anise has been utilized in folk medicine industry because of its soothing and antispasmodic properties (Ludlow et al., 2004). Estragole (4-allyl anisole, 1-methoxy-4-enylbenzene) is a naturally occurring compound which can be extracted from Anise, and Chinese star anise; flavors and fragrances containing estragole are used in food products, perfumes, soaps and detergents (Ismaiel et al., 2016). Verghese (1998) also claimed that, traditionally, the oil of star anise used topically for rheumatism and otalgia and also as an antiseptic. Star anise oil is a pale yellowish liquid (De et al., 2001). A genuine sample of the oil derived exclusively from the fruit displays properties like, the specific gravity at $25^{\circ} \mathrm{C}$ is 0.984 , the refractive index at $25^{\circ} \mathrm{C}$ is 1.5572 , optical roation $-/+$ 0.12 , soluble in 1.5 volumes and more of $90 \%$ ethanol, moreover, its oil is stimulant, eupeptic, carminative, mildly expectorant and diuretic (Verghese, 1998). It has been reported that (E)-Anethole, limonene, linalook, and $\alpha$-pinene are major components of the essential oil of I. verum (De et al., 2002; National Committee for Clinical Laboratory Standards, 2002). Star anise is socially accepted in occasions and is traditionally being used in high altitude regions of Arunachal Pradesh where dried seedless fruits are used as incense, flavouring tea, preparation of butter salted tea or sugar tea for sweet fragrance and to increase and improve the potency and strength of alcohol (Mukhia, 2006). Also, used as medicine to cure cough, toothache and sinusitis, used as an anti-fungal agent and food preservative (Angami et al., 2017). Leaves in combination with juniper/thuja/pine leaves are burnt for making smoke which is believed to be scared and help in purifying surrounding air (Paul et $a l .$, 2013). De et al. (2001) found that its oil is useful in flatulence, spasmodic pains and dysentery, it also relieves colic and is a common ingredient of cough lozenges. Moreover, its osil is used as an applicant in rheumatism and also applicant as an antiseptic. Besides, it is also useful against body lice, bedbugs and is an ingredient of cattle sprays. Other usages of star anise oil is in fevers, scabies, constipation and insomnia. Vecchio et al. (2016) noted that Pimpinella anisum (anised or green anise) and Illicium verum (Chinese star anise or star anise) are both under the name of anise, but each one presents different functional and botanical characteristics. Both Chinese star anise and anise have been widely used in Iranian traditional medicine for antimicrobial effects (Yazdani et al., 2009). It has not only studied for its advantages in food and medicinical science (Ohira et al., 2009), but also it has been studied for its essential oil which is biologically active for both fumigating and repelling S. zeamais, Blattella germanica, Lasioderma serricorne, Sarocladium oryzae, Callosobruchus chinensis, and Aedes aegypti (Ho et al., 1995; Chang and Ahn, 2002; Kim et al., 2003; Dana and Wej, 2006). Gholivand et al. (2009) reported that the dried star anise fruit is almost composed of 49 compounds which may included trans-anethole $(81.40 \%)$, limoene $(6.50 \%)$, chavicol $(2.10 \%)$, and also anisaldehyde (1.81\%). Li et al. (2013) also stated that the dried star anise fruit is composed of nearly 8-12\% essential oil. Star anise primarily contains anethole and fatty oil. It is primarily located in the woody shell, to a lesser extent in the seed. Anethole is only slightly soluble in water but exhibits high solubility in ethanol. Besides, it is distinctly sweet, measuring 13 times sweeter than sugar. The essential oil (anisi aetheroleum) extracted from steam distillation of ripe ob both I. verum and P. anisum contain trans-anethole from 80\%-95\% or more, which is responsible for its characteristics taste and smell, and of course medical properties (Ooi et al., 1994; DerMarderosian and Beutler, 2002), followed by chavicol methyl ether (estragole), anisaldehyde and cisanethole (Hansel et al., 1999). Ismail (2018) mentioned that star anise is one of the most effective oils against $T$. confusum. In traditional Chinese medicine, I. verum has long been used with the actions of dispelling cold and relieving pain (Wang et al., 2011). Parsa et al., (2012) reported that Chinese star anise is used extensively in the both Indian diet and medicine because it does not have any adverse influence and also easily absorbs. They have also found that the oil of star anise is stimulant, stomachic, carminative, mildy expectorant and diuretic. It has been also reported that the fruit of the plant has been used in traditional medicine for treatment of stomach aches, vomiting, rheumatic pain, insomnia and skin inflammation (Sung et al., 2012; Wang et al., 2011; Estevao-Silva et al., 2014; Park et al., 2015). Aly et al. (2014) mentioned that its fruit is an important traditional Chinese medicine as well as a commonly used spice. Mathon et al. (2013) high levels of anisatin in Illicium lanceolatum, I majus, and I anisatum may cause health concerns if they are mididentified or mixed with edible Illicium verum. It is able to increase production of milk new mother (Ibrahim et al., 2016). The use to facilitate birth and to increase the libido, as well as to relieve menopausal discomforts; and its oil is applicant in 
rheumatism as recommended by some folk remedies. Zhang et al. (2005) showed that trans-anethole, panisaldeyde, farnesol, and estragole are main aroma compounds of Chinese star anise. They have also shown that 47 compounds accpunted for more than $90 \%$ in total Chinese star anise aroma molecules, including transanethole $(75.76 \%)$, p-anisaldehyde $(8.65 \%)$, estragole $(4.70 \%)$, farnesol $(3.26 \%)$, limonene $(1.01 \%)$, linalool $(1.44 \%)$, caryophyllene $(1.03 \%)$ and 4 -methoxypropiophenone $(0.72 \%)$. Sripongpun (2008) stated that the crude extract of Chinese star anise can be applied as an optional control of house fly at breeding sites. Classification of Chinese star anise is shown in Table 1. Various pharmacological effects of anethole which is the main ingredient in star anise oil is presented in Table 2. Figure 1 is shown Chinese star anise.

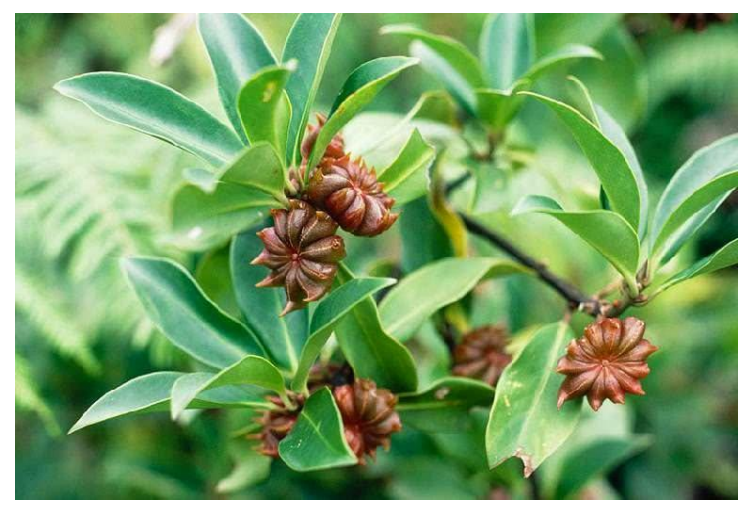

Figure 1. Chinese star anise.

Table 1. Classification of Chinese star anise.

\begin{tabular}{ll}
\hline Kingdom & Plantae \\
Division & Magnoliophyta \\
Class & Magnoliopsida \\
Order & Austrobaileyales \\
Family & Illiciaceae \\
Genus & Illicium \\
Species & Verum \\
\hline
\end{tabular}

Table 2. Various pharmacological effects of anethole which is the main ingredient in star anise oil.

1- $\quad$ Increasing the white blood cellular activity. Some agents such as Shengbaining and Shengzuening, whose main active ingredients were extracted from the star anise, can promote mature white blood cells in the bone marrow to spread into the surrounding blood. Due to the body's own feedback, mature and release speed of bone marrow cells were accelerated. It can also keep bone marrow cells' activity, enhancing the white blood cells (especially granulocytes).

2- Bacteriostatic effect. Star anise oil shows antibacterial effects in a variety of strains (Fu and Li, 2011) including Staphylococcus aureus, Escherichia coli, Bacillus subtilis, theria bacillus, and Salmonella typhi. The results laid a theoretical foundation for the development and utilization of novel plant-derived antifungal propenylbenzene derivatives.

3- Antiviral effects (Koch et al., 2008). Star anise oil can act on different acyclovir-susceptible and acyclovirresistant herpes simplex virus type 1 (HSV-1) strains.

4- Other effects. Anethole can improve the activity of anticholinesterase (Bhadra et al., 2011). It shows significant inhibitory effect against acetylcholinesterase and butyrylcholinesterase, and the $\mathrm{IC}_{50}$ value was $39.89 \pm 0.32$ $\mu \mathrm{g} / \mathrm{mL}$ and $75.35 \pm 1.47 \mu \mathrm{g} / \mathrm{mL}$, which the value for star anise oil was $36.00 \pm 0.44 \mu \mathrm{g} / \mathrm{mL}$ and $70.65 \pm 0.96 \mu \mathrm{g} / \mathrm{mL}$, respectively. It has also been reported that anethole has an antioxidant effect.

Evidence indicate that anethole is natural bioactive compound with multiple beneficial effects in human health such as anti-inflammatory, anticancer, chemopreventive, neuroprotective, spasmolytic, hypotensive, antithrombotic, immunomodulatory, and antidiabetic. It has offer a safe approach in treatment of several chronic diseases, especially in skin and lung inflammatory disorders, cancer, type 2 diabetes and neurological diseases. Domiciano et al. (2013) found that the anethole maybe effective in controlling some nonimmune acute inflammation-related disease, probably by an inhibitory action on production or release of PGE 2 and NO. Wei et 
al. (2014) suggested that $I$. verum fruit extracts and trans-anethole can potentially be developed as a grain protectant to control stored-product insect pests. Li et al. (2013) also found that I. verum which is one of the most important Chinese herb, has possess insecticidal activity against S. zeamais and Cryptolestes pusillus Schnoherr. Other studies have indicated that the essential oil of I. verum has repellent and fumigant actions on S. Zeamais, Blattella germanica (Change and Ahn 2001), Lasioderma serricorne, Sitophilus oryzae, Callosobruchus chinensis (Kim et al. 2003), and Aedes aegypti (Dana and Wej, 2006). Parasa et al. (2012) observed that minimum inhibitory concentration (MIC) values $(\mathrm{mg} / \mathrm{ml}$ ) for Illicum verum Hook fruit against Aeromonas hydrophila, Aeromonas salmonicida and Edwardsiella tarda were 0.15625, 0.078125, and 0.15625. Zhou et al. (2016) suggested that I. verum extracts have potential as an eco-friendly biopesticide in integrated pest management against M. persicae. Wei et al. (2014) also indicated that $I$. verum fruit extracts and transanethole can potentially be developed as a grain protectant to control stored-product insect pests. Liu et al. (2011) found that essential oils of I. verum showed strong attractiveness to the German cockroaches at a concentration of $1 \mathrm{pp}$.

\subsection{Modern medicinal usage of star anise}

An estimated $66 \%$ of China s star anise harvest is used to make Tamiflu. In Guangxi province alone, some 350,000 hectares of farmland are devoted to the star anise tree with an annual output of 80,000 MT. It takes almost $30 \mathrm{~kg}$ of star anise to yield $1 \mathrm{~kg}$ of shikimic acid, enough to treat one person. It has been reported that star anise has antimicrobial, antifungla and antioxidant activities (Chouksey et al., 2010; Benmalek et al., 2013). Padmashree et al. (2007) indicated that powders of star anise and particularly their ethanol/water extracts have great potential as natural antioxidants. Yang et al. (2010) introduced $I$. verum as natural anti-microbials for the treatment of antibiotic pathogens. Abdallah et al. (2013) investigated the antiviral activity of anise oil against bovine herpes virus type 1- (BHV-1) in cell culture and they found that anise oil is non-toxic to MDBK cells up to $100 \mathrm{ug} / \mathrm{ml}$, and also inhibited the growth and development of BHV-1. Sung et al. (2012) recommended star anise in the treatment of inflammatory diseases. Alhajj et al. (2015) indicated that Chinese star anise could be used as a natural additive to improve the immune responsiveness and performance of broiler chickens. One of the most important character of $I$. verum is digestive aid which may make the nursing mothers promote breast milk production, has the anti-bacterial and anti-fungal affection of astham, bronchitis, and dry cough, refreshed the breath, and ensure a good sleep (Cheng and Changli, 2007; Ashraf et al., 2012). Fagundes et al. (2014) concluded that anethole in the essential oil of Illium verum Hook can be identified and determined by GC-MS, NMR and UV-VIS, and a superior HPLC method has been developed for the determination of the compound in rat plasma. Zhang et al. (2015) have examined the characteristics aromatic constituents of star anise, and they have confirmed forty seven compounds, with trans-anethole, estragole, and anisaldehyde the main aroma components. The content of trans-anethole was the highest (75.76\%), followed by linalool (1.44\%), Limonen $(1.01 \%)$, and 4'-methoxypropiophenone $(0.72 \%)$ were the lowest. Bhatti et al. (2017) concluded that the protocatechuic acid residing in I. verum most probably underlies its antioxidant action. Star anise volatile oil could be applied in different industries, like the cosmetic, the pharmaceutical or the food industry; in the latter it might replace the synthetic antioxidant used nowadays in order to overcome the adverse influence of the synthetic additives on the public health (Aly et al., 2016). Economic and medicinal importance of Chinese star anise is shown in Table 3.

\section{Table 3. Economic and medicinal importance of Chinese star anise.}

1- The anti-bacterial and anti-fungal properties of Chinese star anise are useful in the treatment of diseases like asthma, bronchitis and dry cough.

2- Chinese star anise can also be used as for its sedating properties to secure a good sleep.

3- Its osil is appropriate in providing relief from rheumatism and lower back pain.

4- It can also be used as a natural breath freshener.

5- There is a compound present in Chinese star anise which is called Shikimic acid, and it is used for preparing drug for curing influenza or the flu virus.

6- Another important compound present in Chinese star anise which contains anti-oxidants properties is Linalool, and it is good for overall health.

7- $\quad$ The chemical compounds which derived from this important herb also have anti-oxidant, disease preventing and health promoting properties.

8- Anethole is the most important compounds in this herb, but other important compounds found in the seeds include extragol, p-anisaldehyde, anise alcohol, acetophenone, pinene and limonene.

9- In traditional Chinese and Asian medicine, it mainly uses as stomachic, anti-septic, anti-spasmodic, carminative, 
digestive, expectorant, stimulant and tonic.

10- The seeds are excellent source of many essential B-complex vitamins such as pyridoxine, niacin, riboflavin, and thiamin.

11- Seeds are also great source of minerals like calcium, iron, copper, potassium, manganese, zinc, and magnesium.

12- This important spice is also contain good amounts of anti-oxidant vitamins such as vitamin-C and vitamin-A.

Shikimic acid which extracted from I. verum is one of the main ingredients in the antiviral drug Tamiflu used to fight avian influenza (Ohira et al., 2009; Borah, 2013). I. verum has been reported to possess antioxidant properties (Chempakam and Balaji, 2008) as well as significant anticancer potential (Shu et al., 2010). Antioxidant properties may be recommended in enhancing shelf life of products such as spices (Prakash et al., 2011). Natural antioxidants are known to protect cells from damage induced by oxidative stress, which is generally considered to be a cause of ageing, degenerative disease, and cancer (Ringman et al., 2005). Dinesha et al. (2014) concluded that the extracts of star anise exhibited effective prevention ability against $\mathrm{H}_{2} \mathrm{O}_{2}$ induced cell death and DNA protection, and these activities of extracts may due to the presence of polyphenols, proteins and flavonoids in star anise extracts. Chouksey et al. (2013) observed that the extracts of I. verum possess potent central nervous system (CNS) depressant action and anxiolytic effect without interfering with motor coordination. Park et al. (2015) suggested that treatment with Illicium v. maybe the basis of a novel therapeutic strategy for hyperlipidemia-antherosclerosis. Diza et al. (2014) suggested that the combination of chamomile and star anise can be used as an alternative antidiarrheal treatment. Shu et al. (2010) discovered that star anise polysaccharides could inhibit the growth of Sarcoma 180 tumor in vivo. The tumor inhibition ratio of high dose polysaccharides $(720 \mathrm{mg} / \mathrm{kg}$ ) was $30.92 \%$. Kanatt et al. (2014) reported that star anise extract exhibit high reducing power indicating good antioxidant potential, and antioxidant potential of star anise extract was better than lemon grass extract, and the extracts were able to protect against radiation induced DNA damage in pBR322 plasmid. Illicum verum extract may contribute for development of phytotherapic products that could be more cost effective, safer, and more accessible and provide a lower risk of resistance than conventional therapeutic drugs (Sri et al., 2015). Ritter et al. (2014) also found that anethole which has been found in both star anise and anise exerts a peripheral antinociceptive effect without causing sedation. They did propose anethole as an interesting therapeutic alternative in inflammatory and painful diseases. Li et al. (2017) showed that I.verum fruit extracts exhibit considerable potential for M. persicae control programs. Huang et al. (2016) indicated that the cellulase-ultrasonic assisted extraction technology has the potential be used for the industrial production of flavonoids from I. verum. Chinese star anise is commonly used in Iranian traditional medicine as antimicrobial (Amin, 2005), while I. verum has long been used in traditional Chinese medicine with the actions of dispelling cold and relieving pain (Wang et al., 2011). Lenora et al. (2016) concluded that commercial use of star anise could be an alternative for the management of water hyacinth, contributing to solve environmental and economic problems caused by it. Zhou et al. (2016) have found that star anise extracts showed significant inhibitory effects on aerobic bacteria counts; besides, star anise extracts showed antimicrobial activity against amine producers. Peng et al. (2016) have suggested that the SJYB extractives of I. verum had a function in activating the acquired immune response and a huge potential in biomedicine. Diaz et al. (2014) have found that the mixture of star anise and chamomile decreased the completion percentage of the activated carbon, delayed the appearance of diarrhea and decreased the number of evacuations in comparison with the control treatments. They have finally proposed that the combination of chamomile and star anise can be used as an alternative antidiarrheal treatment. Yadav and Bhatnagar (2007) indicate that the treatment with star anise rescues the tumor burden, lowers oxidative stress and increases the level of phase II enzymes, which may contribute to its anticarcinogenic. Both the essential oil from Chinese star anise fruit and trans-anethole are major constituents and exhibit potent inhibitory effect against all test fungi indicating that most of the observed anti-fungal properties was due to the presence of trans-anethole in the oil, which could be developed as natural fungicides for plant disease control in fruit and vegetable preservation (Huang et al., 2010; Vecchio et al., 2016).

\section{Anise}

\subsection{Occurrence and cultivation}

China has important potential to produce aromatic and medical plants and herbs due to its various biological diversity and different climatic conditions (Chen et al., 2013; Ogbaji et al., 2013; Shahrajabian et al., 2017; Yong et al., 2017). Aromatic plants such as anise seed have a long traditional use in both folk and conventional medicine and of course in the pharmaceutical industry (Abouzid and Mohamed, 2011; Ibrahim et al., 2017). Anise (Pimpinella anisum) is a herbaceous annual plant, native to Mediterranean region and primarliy grown for both fruits and seeds (Zand et al., 2013). It has been reported, it is also indigenous to Iran, India and Turkey 
(Kucukkurt et al., 2009). Its fruits, known also as aniseed, were used as traditional medicine in China as early as in the $5^{\text {th }}$ century. Fruits of this plant contain fatty oil, proteins, carbohydrates and cellulos fibers. In European countries consumption of anise fruits is more than its production so the amount of imported anise fruits reached about 2000 t in 2004 (Ullah et al., 2014). Among other countries Germany remains the largest spice importer of anise (Rapisarda 2004). Sirisha and Sujathamma (2018) noticed that anise usually grows on dry rocky places, rocky crevices, fields, meadows, mountains pastures and grasslands, and its seed germination in nature is very poor. The Pimpinella anisum has common names in different countries such as: Anis vert (France); Anise seed (Japan); Anise and Star anise (the USA); Annesella (Italy); Anisa, Badian, Kuppi, Muhuri, Saunf and Sop (Iran and India); Boucage anis, Petit anise (North Africa), and anise (England) (Ross, 2001; Khare, 2007). Anise is shown in Figure 2.

\section{Classification of Pimpinella $L$.}

Kingdom: Plantae

Subkingdom: Tracheobionta

Super division: Spermatophyta

Division: Magnoliophyta

Class: Magnoliopsida

Sub class: Rosidae

Order: Apiales

Family: Apiaceae

Genus: Pimpinella

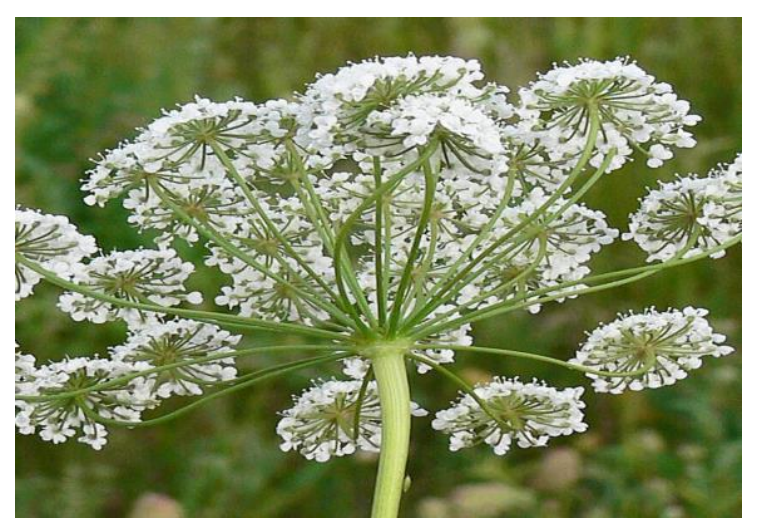

Figure 2. Anise.

\subsection{Anise nutritional composition and chemical constituents}

Anethole which is used in pharmaceutical, food, perfumery and flavouring industry, is the most important constituent of anise (Ozkan and Chalchat, 2006; Tuncturk and Yildirim, 2006). The yield and anethole content of aniseed are affected by the genotype, the ecological conditions and especially by agricultual practices such as the irrigation, plant population, fertilizer and planting date (Asadi-kavan et al., 2009; Ozel, 2009; Acimovic et al., 2014). Apart from anethole, anise is well-known for essential oil which gives it the characteristics odor and aroma. Although, the major component of anise oil is trans-anethole (75-90\%), other constituents include coumarins (umbelliferone, umbelliprenine, bergapten, and scopoletin), lipids (fatty acids, beta-armyrin, stigmasterol and its salts), flavonoids (flavonol, flavone, glycosides, rutin, isoorientin and isovitexin), protein and carbohydrate (Yamini et al., 2008; Picon et al., 2010). It has been reported that apiaceae seed are used in food industry such as bread, biscuits and cookies as ingredients, and in meat industry, Apiaceae are favorable spices. (Acimovic et al., 2015). Mean values or components of anise essential oil analyzed by GC-MS is presented in Table 4. Anise methanolic extract and molecular formula is shown in Table 5. Oil content and fatty acid composition of anise is presented in Table 6. 
Table 4. Mean values or components of anise essential oil analyzed by GC-MS (Ullah et al., 2013).

\begin{tabular}{llll}
\hline No. & Components & Kovats retention index & \% \\
\hline 1 & Estragol & 1197 & 0.33 \\
2 & Cis-Anethole & 1252 & 0.14 \\
3 & Trans-Anethole & 1287 & 82.1 \\
4 & $\delta$-Elemene & 1333 & 0.45 \\
5 & $\beta$-Elemene & 1388 & 0.08 \\
6 & $\alpha$-Himachalene & 1449 & 0.71 \\
7 & $\gamma$-Himachalene & 1478 & 7.0 \\
8 & $\alpha$-Amorphane & 1482 & 0.15 \\
9 & (E)-Methylisoeugenol & 1489 & 0.14 \\
10 & $\alpha$-Zingiberene & 1493 & 0.77 \\
11 & $\beta$-Himachalene & 1499 & 0.44 \\
12 & $\alpha$-Muurolene & 1502 & 0.15 \\
13 & $\beta$-Bisabolene & 1506 & 0.38 \\
14 & $\beta$-Sesquipehllandrene & 1522 & 0.05 \\
15 & Spathulenol & 1580 & 0.04 \\
16 & Unknown & 1629 & 0.05 \\
17 & $\alpha$-Cadinol & 1651 & 0.08 \\
18 & Unkown & 1831 & 5.95 \\
19 & Unknown & 1886 & 0.92 \\
\hline
\end{tabular}

No. of identified compounds.

Table 5. Anise methanolic extract and molecular formula.

\begin{tabular}{lll}
\hline No. & Compound Name & Molecular Formula \\
\hline 1 & Anethole & $\mathrm{C}_{10} \mathrm{H}_{12} \mathrm{O}$ \\
2 & Varidiflorene & $\mathrm{C}_{15} \mathrm{H}_{24}$ \\
3 & Eicosane & $\mathrm{C}_{20} \mathrm{H}_{42}$ \\
4 & Docosane & $\mathrm{C}_{22} \mathrm{H}_{46}$ \\
5 & Nonadecane & $\mathrm{C}_{19} \mathrm{H}_{40}$ \\
6 & Pentadecane & $\mathrm{C}_{15} \mathrm{H}_{32}$ \\
7 & Butanoic acid & $\mathrm{C}_{15} \mathrm{H}_{20} \mathrm{O}_{3}$ \\
8 & Heneicosane & $\mathrm{C}_{21} \mathrm{H}_{44}$ \\
9 & Octacosane & $\mathrm{C}_{28} \mathrm{H}_{58}$ \\
10 & Hexadecane & $\mathrm{C}_{20} \mathrm{H}_{42}$ \\
11 & Cyclohexane & $\mathrm{C}_{26} \mathrm{H}_{50}$ \\
\hline
\end{tabular}

Table 6. Oil content and fatty acid composition of anise (Alfekaiki, 2018).

\begin{tabular}{ll}
\hline Element & Mineral contents (\%) \\
\hline Carbon & 34.5 \\
Oxygen & 21.1 \\
Nitrogen & ND \\
Aluminum & 20.5 \\
Bromine & 14 \\
Iron & ND \\
Copper & 3.63 \\
Lanthanum & 5.85 \\
Palladium & 0.35 \\
Sulfur & 0.15 \\
Potassium & ND \\
Magnesium & ND \\
\hline
\end{tabular}




\subsection{Potential health benefits, medicinal uses of anise in modern medicine industry}

Seeds of anise are used as analgesic in migraine and also as carminative, aromatic, disinfectant and diuretic in traditional medicine (Amin, 2005). In some traditional texts, anise is mentioned for melancholy, nightmare, and also in treatment of epilepsy and seizure (Mirheydar, 2001). Shobha (2013) noticed that aniseed is a potent antiperoxidative and anti-diabetic agent and thereby, possess a vast spectrum of applications and exploitations in the food and drug industry. Ciftci et al. (2005) showed that anise oil has anethole as active ingredients and also eugenol, methylchavicol, anisaldehyde and estragole. Rebey et al. (2017) revealed that aniseeds might constitute a novel source of natural antioxidants and could be used as food additive. Acimovic et al. (2014) found that drought cause a significant decrease in thousand seed weight, germination energy and total germination as well as essential oil content in anise. Contrary to this finding, the content of trans-anethole was significantly higher in the dry year. Ibrahim (2008) reported that according to the traditional thinking, drinking anise by boys maybe harmful to their reproductive system. Kreydiyyeh et al. (2003) found that extracts of the aniseeds are used as medicine for their diuretic and laxative effect, expectorant and anti-spasmodic action, and their ability to ease gastric pain and flatulence. Ibrahim et al. (2017) reported that waste residues of anise and star anise are promising new sources of phenolic antimicrobial compounds which offer new commercial opportuities to pharmaceutical industry. They have suggested that combination of anise waste extracts with some antibiotics leads to new choice for treatment of infectious diseases and waste extracts may act as activity modifying agent for antibiotics. Islam et al. (2016) reported that aniseed extracts showed positive antibacterial effects on only three bacteria, named, Bacillus cereus, Bacillus subtilis and Streptococcus pneumonae. They have also found that the phytochemical analysis of the aqueous extract revealed the presence of alkaloids, flavonoids, saponins, tannins, terpenoids, phenolic compouns and cardiac glycosides. Fouda et al. (2014) indicated that the anise extract shows good performance as corrosion inhibitor $1 \mathrm{M} \mathrm{HCl}$, and also the anise extract inhbits the corrosion by getting adsorbed on the etal surface following Langmuir adsorption isotherm. Uysal et al. (2007) reported that fruits of anise use for treatment of infections, angina, bronchitis, gastritis, laryngitis and migraine. Mohamed et al. (2015) showed that the petroleum ether, chloroform, ethyl acetate and methanol extracts of $P$. anisum (1:10 and 2:10) were highly active $(30-40 \mathrm{~mm})$ against $B$. subtilis. The ethyle acetate extract exhibited moderate activity $(15 \mathrm{~mm})$ against $E$. coli and low activity $(13 \mathrm{~mm})$ against $P s$. aeruginosa. The methanol extract of $P$. anisum showed high activity $(16 \mathrm{~mm})$ against $E$. coli, low activity $(13 \mathrm{~mm})$ against $P$ s. aeruginosa, and the methanol extract have variable activity against all test organisms. Yazdani et al. (2009) concluded that anise can be a candidate for further studies due to their antifungal potencies. Rebey et al. (2019) indicated that the determination of optimal periods and provenances for antioxidant accumulation can be used to evaluate the quality of aniseeds and could be important for industries. Khudor et al. (2013) mentioned that Pimpinella anisum and some antibiotics by disc diffusion methods and minimum inhibitory concentration, the results showed these bacterial isolates were sensitive to the aqueous extract compared with methanol, acetone and petroleum ether and were more sensitive to vancomycin compared with other antibiotics. Karimzadeh et al. (2012) indicated the anticonvulsant and neuroprotective effects of anise oil, likely via inhibition of synaptic plasticity. Bagdassarian et al. (2013) stated that the seeds of anise are rich in phytochemical contents, which possessed high antioxidant and antimicrobial activities and they can be used for health supplement and pharmaceutical benefits. Aydemir et al. (2015) observed that trand-anethole has the potential to inhibit QS (Quorum sensing)-regulated virulence factors in P. aeruginosa by binding to LasR protein, similar to its natural ligand $N$-(3-oxododecanoyl)-L-homoserine lactone. Mahood (2012) concluded that anise oil extract can decrease signs of polycystic ovary syndrome (PCOS) in the ovarian tissue and altered concentrations of luteinizing hormone. Singh et al. (2008) stated that the antioxidant potency of anise oil and its methanol and ethanol oleoresins, can be utilized for protecting fat-containing foods. Diaz et al. (2014) stated that mixture of chamomile and star anise decrease the completion percentage of the activated carbon, delayed the appearance of diarrhea and decrease the number of evacuations in comparison with the control treatments. They have suggested the combination of chamomile and star anise as an alternative antidiarrheal treatment. Ibrahim (2008) concluded that anise oil administration inhibited GST expression, besides decreasing testosterone, T3 and T4 hormones and inhibiting sperm counts and sperm motility. Al-Omari et al. (2018) concluded that anise possesses immunomodulatory activity when apply orally in mice and selectively activates cell-mediated immune mechanisms. Ciftci et al. (2005) indicated that anise is an annual herb indigenous to Iran, India, Turkey and many other warm regions and it could be considered as a potential natural growth promoter for poultry. Amina et al. (2016) showed that the aqueous extract of $P$. anisum $L$. can have a corrective effect against nephrotoxicity induced by lead, so $P$. anisum $L$. has a beneficial impact on the kidneys intoxiciated with lead acetate. Mosaffa-Jahromi et al. (2017) suggested that anise oil could be a promising choice of treatment for depressed patients with irritable bowel syndrome. Shahamat et al. (2015) concluded that $P$. anisum possesses an 
antidepressant-like activity similar to that of fluoxetine, which has a potential clinical value for application in the management of depression. Felsociova et al. (2015) reported that the most hopeful antifungal activity and killing effect against all tested penicillia was found to be Pimpinella anisum and Origanum vulgare L. Rattan et al. (2014) showed that a formulation of biscuits with anise extract was prepared for enhancing the healthy beneficial usage of biscuits and nutraceutical, in conditions like cough or sore throat with a simultaneous attainment of the other health benefits. Kargozar et al. (2017) stated that Pimpinella anisum is effective in the treatments of acute menopausal syndrome with different mechanisms. Barbalho et al. (2015) suggested that $P$. anisum has potential to be used to control lipid levels. Radaelli et al. (2016) the use of essential oil from anise might serve as an alternative to the use of cheical preservaties in the control and inactivation of pathogens in commercially produced food systems. Kucukkurt et al. (2009) demonstrated that aniseed could be used at 30 $\mathrm{g} / \mathrm{Kg}$ level in quail diets an increased antioxidant activity with glutathion (GSH) and a decreased blood malondialdehyte (MDA) levels. Shahamat et al. (2016) suggested that $P$. anisum possesses an antidepressantlike activity similar to that of fluoxetine, which has a potential clinical value for application in the management of depression. Abdel-Reheem and Oraby (2015) found that Pimpinella anisum essential oil residuals have high inhibitory effect for Salmonella typhi, Enterococcus faecalis, Staphylococcus aureus, Escherichia coli and Micrococcus Iuteus. Pavela (2014) stated has the essential oil from Pimpinella anisum fruits and trans-Anethole were toxic for Daphnia magna (62-92\% mortality) and significantly reduced it fertility at high concentrations $\left(35-50 \mu \mathrm{L} \mathrm{mL}^{-1}\right)$ and long exposure $(48 \mathrm{~h})$. However, no negative effect on Daphnia mortality or fertility was found at shorter exposure times $(6 \mathrm{~h})$ and lower concentrations $\left(20 \mu \mathrm{L} \mathrm{mL}^{-1}\right)$. Womeni et al. (2013) found that the powder of Pimpinella anisum has a special potent antioxidants for stablization of crude soybean oil. Changizi et al. (2017) observed that the simultaneous use of ethanolic extract of $P$. anisum during gerntamicin (GM) administration is recommended to reduce its nephrotoxicity effects. Barbalho et al. (2015) reported that $P$. anisum has potential to be used to control lipid levels. Kadan et al. (2013) noted that anise could be one of the foods that attribute to cancer prevention and treatment. It could be a natural source of novel anticancer compounds with anti proliferative and apoptotic properties. Bekara et al. (2015) observed that aniseed aqueous extract was effective in reducing the level of some of biochemical parameters and ameliorate behavior of intoxicated rats by lead. Nahidi et al. (2012) concluded that $P$. anisum is effective on the frequency and severity of hot flashes in postmenopausal women. Hosseinzadeh et al. (2014) stated that $P$. anisum aqueous and ethanolic extracts can increase milk production in rats. Sharifi et al. (2008) reported that anise is commercially cultivated in Iran and has been used in medicinal applications; moreover, their oil can be effective for protection of fresh fruits facing fungi and its essential oil can be considered as a potential, broad spectrum and safe substitute of chemical agents. Ashraffodin Ghoshegir et al. (2015) showed the effectiveness of anise in relieving the symptoms of postpartum depression. Shirzadi et al. (2017) noted that $P$. anisum ethanolic extract is effective in suppression of morphine physical dependence and further studies are needed to find out the responsible constituents and also the exact mechanisms of actions. Nikoskhan et al. (2015) observed that 250 and 300 $\mathrm{mg} / \mathrm{kg}$ of hydroalcoholic extract of $P$. anisum seed significantly increased the duration of open arm ledges and decreased the duration of closed arm ledges in maze; in addition, this treatment resolved anxiety and relieved anxiety in rats. Nikfarjam et al. (2016) described that Pimpinella anisum is one the most important native medicinal plants of Iran with anti-anxiety properties. Amini et al. (2018) identified components of the essential oils and obtained results showed that Pimpinella anisum L. showed the most fumigant toxicity on the storage pests. The pharmacological effects of Pimpinella anisum is shown in Table 7.

Table 7. The pharmacological effects of Pimpinella anisum (Shojaii and Abdollahi Fard, 2012).

\begin{tabular}{ll}
\hline System & Effect \\
\hline Organism & Antibacterial \\
& Antifungal \\
& Insecticidal \\
& Antiviral \\
Muscle & Muscle relaxant of tracheal chain \\
& Antispasmodic and relaxant of anococygeus smooth muscle \\
Nervous system & Anticonvulsant \\
& Analgesic \\
& Conditioned place aversion in morphine dependence \\
Gastrointestinal & Laxative \\
& Increase glucose absorption from the jejunum \\
Renal & Reduce volume of urine by increase activity of the renal $\mathrm{Na}^{+}-\mathrm{K}^{+}-\mathrm{ATPase}$ \\
\hline
\end{tabular}




\begin{tabular}{ll}
\hline Endocrine & Antidiabetic \\
& Hypolipidemic \\
Immune system & Antioxidant \\
Others & Reduction of menopausal hot flashed \\
& Growth promoter of day-old broilers \\
& Reduction of pain in dysmenorrhea \\
\hline
\end{tabular}

\section{Conclusions}

Aromatic and medicinal plants are gifts of nature which have been used against different diseases since the beginning of the history. Star anise (Illicium verum Hook. f.) is one of the most famous evergreen tree which has originally distributed in tropic and subtropic areas of Asia, especially China, and it is famous as in traditional Chinese medicine as well as traditional Asian medicine. Its fruit also commonly used spice. Chinese star anise together with the morphological similar Japanese star anise together with the morphologically similar Japanese star anise (Illicium anisatum), is also used for decoration purposes. The Japanese star anise is extremely toxic and is not edible in any form. It has been reported that (E)-Anethole, limonene, linalool, and $\alpha$-pinene are major components of the essential oil of I. verum. The most important compounds of Chinese star anise are $\alpha$-Pinene, $\beta$-Pinene, Myrcene, $\alpha$-Phellandrene, 3-Carene, $\alpha$-Terpinene, $\mathrm{p}$-Cymene, Limonene, Trans-Ocimene, Cis- $\beta$ Ocimene, $\boldsymbol{\gamma}$-Terpinene, Terpinolene, Linalool, $\gamma$-Terpineol, 4-Terpineol, $\alpha$-Terpineol, Estragole, Cis-Anethole, Trans-Anethole, $\alpha$-Cubebene, $\beta$-Clemene, Caryophyllene, Bergamotene, $\Delta$-Cardinene, and $\alpha$-Cadinol. Star anise is one of the many species that contain bioactive compounds as well as a number of phenolic and flavonoid compounds, having antioxidant, preservative and antimicrobial properties. Star anise considered as the main source of shikimic acid, which is the most important ingredient of Tamiflu drug. Chinese star anise has antibacterial and anti-fungal characters, and it is useful in treatment of diseases like asthma, bronchitis and dry cough, it is also good to having a good sleep; it is a natural breath fresher, one of its most compounds is Shikimic which is used as a drug in curing influenza and flu virus; it consists of Linalool which is good for overall health because of its anti-oxidants characters. Its seeds are good source of minerals like calcium, iron, copper, potassium, manganese, zinc, and magnesium. Important compounds found in anise seed include estragol, p-anisaldehyde, anise alcohol, acetophenone, pinene, and limonene, but the most important volatile oil that gives the characteristic sweet, aromatic flavor to seeds is anethole. The recent studies have shown that anise seeds and essential oil have antioxidant, antibacterial, antifungal, anticonvulsant, anti-inflammatory, analgesic, gastro-protective, antidiabetic and antiviral activities. Other important benefits of anise seeds are stimulant, carminative, expectorant, insecticide, vermifuge, digestive, antispasmodic, anti-rheumatic, antiseptic, antiepileptic, anti-hysteric, culinary significance, keeps the heart strong by its importance role to control the blood pressure, one of the best gas-releasing agent, easing many hormonal problems in females, hair benefits, skin benefits and it may reduce symptoms of depression. Anise seed and its extract also use in savory dishes, baked goods, and different drinks in both ancient and modern time. Anise seeds are good source of many essential Bcomplex vitamins such as pyridoxine, niacin, riboflavin and thiamin. The seeds are also important source of minerals like calcium, copper, potassium, iron, manganese, magnesium and zink. Anti-oxidant vitamins such as vitamin $\mathrm{C}$ and $\mathrm{A}$ are also foundable in the spice. Combined with a nutritious diet, other traditional Chinese and Asian medicine, Chinese star anise and ansie seed may improve various aspects of health.

\section{Conflict of interest}

None to declare.

\section{References}

Abdallah FM, H Sobhy and G Enan, 2013. Evaluation of antivital activity of selected anise oil as an essential oil against bovine herpes virus type-1 in vitro. Glob. Vet., 10: 496-499.

Abouzid SF and AA Mohamed, 2011. Survey on medicinal plants and spices used in Beni-Sueif, Upper Egypt. J. Ethnobiol., 7: 18.

Acimovic MG, J Korac, G Jacimovic and S Oljaca, 2014. Influence of ecological conditions on seeds traits and essential oil contents in anise (Pimpinella anisum L.). Notulae Botanicae Horti Agrobotanici Cluj-Napoca, 42: 232-238.

Acimovic MG, LM Kostadinovic, SJ Popovic and NS Dojcinovic, 2015. Apiaceae seeds as functional food. Journal of Agricultural Sciences, 60: 237-246. 
Acimovic M, J Stankovic, M Cvetkovic, B Kiprovski and A Popovic, 2017. Comparative analysis of chemical composition of essential oils from aniseed (Pimpinella anisum L.) and star anise (Illicium verum Hook.). Annals of Agronomy, 41: 9-15.

Alfekaiki DF. 2018. Chemical and physical characteristics and fatty acid profile of some oil seeds of Apiaceae family in Iraq. Chemical and Process Engineering Research, 58: 17-27.

Alhajj MS, M Alhobaishi, AR Ger El Nabi and SL Al-Mufarrej, 2015. Immune responsivenss and performace of broiler chickens fed a diet supplemented with high levels of Chinese star anise fruit (Illicium verum Hook. f). J. Anim. Vet. Adv., 14: 36-42.

Al-Omari MM, AM Qaqish and KM Al-Qaoud, 2018. Immunomodulatory effect of anise (Pimpinella anisum) in BALB/c mice. Trop. J. Pharm. Res., 17: 1515-1521.

Aly SE, BA Dabry, MS Shaheen and AS Hathout, 2014. Assessment of antimycotoxigenic and antioxidant activity of star anise (Illicium verum) in vitro. Journal of the Saudi Society of Agricultural Sciences. http://dx.doi.org/10.1016/j.jssas.2014.05.003

Aly SE, BA Sabry, MS Shaheen and AS Hathout, 2016. Assessment of antimycotoxigenic and antioxidant activity of star anise (Illicium verum) in vitro. Journal of the Saudi Society of Agricultural Sciences, 15: 2027.

Amin G, 2005. Popular medicinal plants of Iran. Iran: Tehran University of Medical Sciences, pp. 38-162.

Amina B, AH Nadia, S Kahloulakhaled, Nesrine and A Abdelkader, 2016. Nephroprotective effect of Pimpinella anisum L. aqueous extract against lead toxicity: In vivo study. Int. J. Green Pharm., 10: 91.

Amini Sh, F Tajabadi, M Khani, MR Labbafi and M Tavakoli, 2018. Identification of the seed essential oil composition of four apiaceae species and comparison of their biological effects on Sitophilus oryzae L. and Tribolium castaneum (Herbst.). Journal of Medicinal Plants, 17: 68-76.

Angami T, R Bhagawati and N Khatri, 2017. Star anise (Illicium Griffithii Hook. F. and Thomas.): A socially important tree species from high altitude region of Arunachal Pradesh. Indian Forester, 143: 309-391.

Asadi-kavan Z, M Ghorbanli, M Pessaraki and A Sateei, 2009. Effect of polyethylene glycol and its interaction with ascorbate on seed germination index in Pimpinella anisum L. Journal of Food, Agriculture and Environment, 7: 662-666.

Ashraf MA, MJ Maah and I Yusoff, 2012. Assessment of phytoextraction efficiency of naturally growth plant species in the former tin mining cathcment. Fresenius Environmental Bulletin, 21: 523-533.

Ashraffodin Ghoshergir S, M Mazaheri, A Ghannadi, A Feizi, M Babaeian, M Tanhaee, M Karimi and P Adibi, 2015. Pimpinella anisum in the treatment of functional dyspepsia: A double-blind, randomized clinical trial. Journal of Research in Medical Sciences, 20: 13-21.

Aydemir DH, G Cifci, V Aviyente and G Bosgelmez-Tinaz, 2018. Quorum-sensing inhibitor potential of transanethole against Pseudomonas aeruginosa. J. Appl. Microbiol., April 2018. 9 pages.

Bagdassarian VLC, KS Bagdassarian and MS Atanassova, 2013. Phenolic profile, antioxidant and antimicrobial activities from the Apiaceae family (dry seeds). Mintage Journal of Pharmaceutical and Medical Sciences, 2: 26-31.

Barbalho SM, AC Araujo, EL Guiguer, MSSS Souza, PC Bueno and CG Mendes, 2015. Comparative evaluation of Baccharis trimera, Pimpinella anisum and statin on the biochemical profile of Wistar rats. International Journal of Phytomedicine, 7: 354-358.

Bekara A, N Ait hamadouche, K Kahloula, S Harouat, D Tabbas and AEK Aoues, 2015. Effect of Pimpinella anisum $L$. (Anissed) aqueous extract against lead $(\mathrm{Pb})$ neurotoxicity: neurobehavioral study. International Journal of Neuroscience and Behavioral Science, 3: 32-40.

Benmalek Y, O Yahia, A Belkebir and ML Fardeau, 2013. Anti-microbial and anti-oxidant activities of Illicium verum, Crataegus oxyacantha ssp monogyna and Allium cepa red and white varieties. Bioengineered, 4: 244248.

Bhadra S, PK Mukherjee, MS Kumar MS, et al., 2011. Anticholinesterase activity o standardized extract of Illicium verum Hook. f. fruits. Fitoterapia, 82: 342.

Bhatti HA, S Khan, S Faizi, G Abbas, I Ali, S Jawaid, AN Akbar Ali, R Jamy, F Shahid, MA Versiani and A Dar, 2017. Protocatecheuic acid underlies the antioxidant activity exhibited by Illicium verum fruit. Journal of Analytical \& Pharmaceutical Research, 6: 00177.

Borah JC, 2015. Shikimic acid: a highly prospective molecule in pharmaceutical industry. Current Science, 109: 1672-1679.

Chang KS and YJ Ahn, 2001. Fumigant activity of (E)-anethole identified in Illicium verum fruit against Blattela germanica. Pest Management Science, 58: 161-166. 
Changizi-Ashtiyani S, A Seddigh, H Najafi, N Hossaini, A Avan, A Akbary, M Manian and R Nedaeinia, 2017. Pimpinella anisum $L$. ethanolic extract amerliorates the gentamicin induced nephrotoxicity in rats. Nephrology, 22: 133-138.

Chempakam B and S Balaji, 2008. Star Anise. United Kingdom: CAB International. 319-330.

Cheng P and H Changli, 2007. Processing and exploitation of Star Anise. Agric. Prod. Proc., 6: 39-43.

Chen F, J Xie, W Zheng, Y Liu, TP Lu, Q Zhao, Y Hu and MH Shahrajabian, 2013. The status quo of desertification and the prevention strategy in Xinjiang. Journal of Food, Agriculture and Environment, 11: 1025-1032.

Chouksey D, P Sharma and RS Pawar, 2010. Biological activities and chemical constituents of Illicium verum hook fruits (Chinese star anise). Der Pharmacia Sinica, 1: 1-10.

Cifti M, T Guler, B Dalkilic and O Nihat Ertas, 2005. The effect of anise oil (Pimpinella anisum L.) on broiler performance. Int. J. Poult. Sci., 4: 851-855.

Dana C and C Wej, 2006. Essential oils as potential adulticides against two populations of Aedes aegypti, the laboratory and natural field stains, in Chiang Mai province, northern Thailand. Parasitol. Res., 99: 715-721.

De M, AK De, R Mukhopadhyay, M Miro and AB Anerjee, 2001. Antimicrobical actions of Illicium verum Hook. f. Ars Pharmaceutica, 42: 209-220.

De M, AK De, P Sen and Ab Banerjee, 2002. Antimicrobical properties of star anise (Illicium verum Hook $f$ ). Phytother. Res., 16: 94-95.

DerMarderosian AH and JA Beutler, 2002. The review of natural products: the most source of natural product information. $2^{\text {nd }}$ ed. St Louis: Facts and comparisons.

Diaz A, I Vargas-Perez, L Aguilar-Cruz, R Calva-Rodriguez, S Trevino, B Venegas and IR Contreras-Mora, 2014. A mixture of chamomile and star anise has anti-motility and antidiarrheal activities in mice. Revista Brasileira de Farmacognosia, 24: 419-424.

Dinesha R, SS Thammannagowda, KL Shwetha, MSL Prabhu and S Leela, 2014. The antioxidant and DNA protectant activities of Star Anise (Illicium verum) aqueous extracts. J. Pharmacogn. Phytochem., 2: 98-103.

Domiciano TP, MM de Oliveria Dalalio, EL Silva, AMV Ritter, CF Estevao-Silva, FS Ramos, SM CaparrozAssef, RKN Cuman and CA Bersani-Amado, 2013. Inhibitory effect of anethole in nonimmune acute inflammation. Naunyn-Schmiedeberg 's Arch Pharmacol, 386: 331-338.

Elmasry TA, NH Al-Shaalan, E Tousson, K El-Morshedy and A Al-Ghadeer, 2018. Star anise extracts modulation of reproductive parameters, fertility potential and DNA fragmentation induced by growth promoter Equigan in rat tests. Braz. J. Pharm. Sci., 54: e17261.

Estevao-Silva CF, R Kummer, FC Fachini-Queiroz, R Grespan, G Alcantara, N de Melo, S Baroni, RKN Cuman and CA Bersani-Amado, 2014. Anethole and eugenol reduce in vitro and in vivo leukocyte migration induced by fMLP, $\mathrm{LTB}_{4}$, and carrageenan. Journal of Natural Medicines. DOI 10.1007/s11418-014-0839-7

Fagundes VHV, RJ Pinho, LAM Wiirzler, E Kimura, CA Bersani-Amado and RKN Cuman, 2014. High performance liquid chromatography method for the determination of anethole in rat plasma. Trop. J. Pharm. Res., 13: 793-799.

FAO, 1993. Beer, J. H. de (ed.) Non-wood Forest Products in Inochina-Focus: Vietnam. FAO Regional office for Asia and Pacific, Bangkok.

Felsociova S, M Kacaniova, E Horska, N Vukovic, L Hleba, J Petrova, K Rovna, M Stricik and Z Hajduova, 2015. Antigunfal activity of essential oils against selected terverticillate penicillia. Ann. Agr. Env. Med., 22: $38-42$.

Fouda AS, GY Elewady, K Shalabi and S Habouba, 2014. Anise extract as green corrosion inhibitor for carbon steel in hydrochloric acid solutions. International Journal of Innovative Research in Science, Engineering and Technology, 3: 11210-11228.

Fritz E, MS Olzant and R Langer, 2008. Illicium verym Hook. f. and Illicium anisatum. L. Anatomical characters and their values for differentiation. Scientia Pharmaceutica, 76: 65-76.

$\mathrm{Fu} \mathrm{MD}$ and $\mathrm{CH} \mathrm{Li}, 2011$. Extraction progress of star anise oil and its antibacterial and antioxidative effects. China Med Her, 8: 29.

Ghazanfarpour M, R Sadeghi, S Abdolahian and RL Roudsari, 2016. The efficacy of Iranian herbal medicines in alleviating hot flashes: A systematic review. Int. J. Reprod. Biomed., 14: 15-166.

Gholivand MBM and H Rahimi-Nasrabadi Chalabi, 2009. Determination of essential oil components of star anise (Illicium verum) using simultaneous hydrodistillation-rice headspace liquid-phase microextraction-gas chromatography mass spectrometry. Anal. Lett., 42: 1382-1397.

Hansel R, O Sticher and E Steinegger, 1999. Pharmakognosie-Phytopharmaize. $6^{\text {th }}$ ed. Berlin: Springer. 
Ho SH, Y Ma, PM Goh and IY Sim, 1995. Star anise, Illicium verum Hook. f. as a potential grain protectant against Tribolium castaneum (Herbst) and Sitophilus zeamais Motsch. Postharvest Biology and Technology, 6: 341-347.

Hosseinzadeh H, M Tafaghodi, S Abedzadeh and E Taghiabadi, 2014. Effect of aquous and ethanolic extracts of Pimpinella anisum L. seeds on milk production in rats. Journal of Acupuncture and Meridian Studies, 7: 211216.

Howes MJR, GC Kite and MSJ Simmonds, 2009. Distinguisghing Chinese star anise from Japanese star anise using thermal desorption-gas chromatography-mass spectrometry. J. Agric. Food Chem., 57: 5783-5789.

Huang Y, J Zhao, L Zhou, J Wang, Y Gong, X Chen, Z Guo, Q Wang and W Jiang, 2010. Antifungal activity of the essential oil of Illicium verum fruit and its main component trans-anethole. Molecules, 15: 7558-7569.

Huang D, X Zhou, J Si, X Gong and S Wang, 2016. Studies on cellulase-ultrasonic assisted extraction technology for flavonoids from Illicium verum residues. Chem. Cent. J., 10: 1-9.

Ibrahim AAEM, 2008. Correlation between fennel- or anise-oil administration and damage to the testis of adult rats. Egypt. J. Biol., 10: 62-76.

Ibrahim MK, ZA Mattar, HH Abdel-Khalek and YM Azzam, 2017. Evaluation of antibacterial efficacy of anise wastes against some multidrug resistant bacterial isolates. J. Radiat. Res. Appl. Sc., 10: 34-43.

Ismaiel OA, E Abdelghani, H Mousa, SI Eldahmy and Bayoumy, 2016. Determination of estragole in pharmaceutical products, herbal teas and herbal extracts using GC-FID. J. Appl. Pharm. Sci., 6: 144-150.

Ismail EH, 2018. Toxicity, repellency and latent effects of some medicinal oils against Tribolium confusum and T. castaneum (Coleoptera: Tenebrionidae). J. Entomol. Zool. Stud., 6: 1337-1347.

Itoigawa M, C Iyo, H Tokuda, F Enjo, H Nishino and H Furukawa, 2004. Cancer chemopreventive activity of phenylpropanoids and phytoquinoids from illicium plants. Cancer Letters, 214: 165-169.

Joshi VC, PV Srinivas and PV Khan, 2005. Rapid and easy identified of Illicium verum Hook. f. and its adulterant Illicium anisatum Linn. By fluorescent microscopy and gas chromatography. Journal of AOAC International, 88: 703-706.

Kadan S, M Rayan, A Rayan, 2013. Anticancer activity of anise (Pimpinella anisum L.) seed extract. The Open Nutraceuticals Journal, 6: 1-5.

Kanatt SR, SP Chawla and A Sharma, 2014. Antioxidant and radio-protective activities of lemon grass and star anise extracts. Food Biosci., 6: 24-30.

Kang P, KY Kim, HS Lee, SS Min and GH Seol, 2013. Anti-inflammatory effects of anethole in lipopolysaccharide-induced acute lung injury in mice. Life Sci., 93: 955-961.

Kargozar R, H Azizi and R Salari, 2017. A review of effective herbal medicines in controlling menopausal symptoms. Electronic Physician, 9: 5826-5833.

Karimzadeh F, M Hosseini, D Mangeng, H Alavi, GR Hassanzadeh, M Bayat, M Jafarian, H Kazemi and A Gorji, 2012. Anticonvulsant and neuroprotective effects of Pimpinella anisum in rat brain. BMC Complem. Altern. M., 12: 76.

Kim SI, JY Roh, DH Kim, HS Lee and YJ Ahn, 2003. Insecticidal activities Sitophilus oryza and Callosobruchus chinensis. J. Stored Prod. Res., 39: 293-303.

Khare CP, 2007. Indian Medicinal Plants: An Illustrated Dictionary Springer: New York.

Khudor MH, AS Jasim, A Malik and HA Zahra, 2013. Isolation and identification of some bacterial isolates from mercury and photo filling of teeth and study the antibacterial effect of Pimpinella anisum. Journal of University of Thi-Qar, 8: 8-20.

Koch C, J Reichling and R Kehm, et al., 2008. Efficacy of anise oil, dwarf-pine oil and chamomile oil against thymidine-kinase-positive and thymidine-kinase-negative herpesviruses. J. Pharm. Pharmacol., 60: 1545.

Kreyidyyeh SI, J Usta, K Knio, S Markossian and S Dagher, 2003. Aniseed oil increases glucose absorption and reduces urine output in the rat. Life Sci., 74: 663-673.

Kucukkurt I, G Avci, A Eryavuz, I Bayram, IS Cetingul, A Burhaneddin Akkaya and C Uyarlar, 2009. Effects of supplementation of aniseed (Pimpinella anisum L.) at various amounts to diets on lipid peroxidation, antioxidant acitivty and some biochemical parameters in laying quails (Coturnix coturnix japonica). Kocatepe Vet. J., 2: 1-5.

Kudo Y, JI Oka and K Yamada, 1981. Anisatin a potent GABA antagonist, isolated from Illicium cristatum. Neurosci. Lett., 25: 83.

Lederer I, G Schulzki, J Gross and J Steffen, 2006. Combination of TLC and HPLC-MS/MS methods. Approach to a rational quality control of Chinese star anise. J. Agric. Food Chem., 54: 1970-1974. 
Lenora LM, D Suresh Babu, J Senthil Kumar and N Senthil Kumar, 2016. Eichhornia crassipes (Mart.) Solms. An alternate renewable source for shikimic acid, a precursor for Tamiflu, a swine flu drug. J. Pharmacogn. Phytochem., 5: 178-181.

Li SG, MY Li, YZ Huang, RM Hua, HF Lin, YJ He, LL Wei and ZQ Liu, 2013. Fumigant activity of Illicium verum fruit extracts and their effects on the acetylcholinesterase and glutathione S-transferase activities in adult Sitophilus zeamais. J. Pest. Sci., 86: 677-683.

Li SG, BG Zhou, MY Li, S Liu, RM Hua and HF Lin, 2017. Chemical composition of Illicium verum fruit extract and its bioactive against the peach- potato aphid, Myzus persicae (Sulzer). Arthropod-Plant Interactions, 11: 203-212.

Liu ZL, M Yu, XM Li, T Wan and SS Chu, 2011. Repellent activity of eight essential oils of Chinese medicinal herbs to Blattella germanica L. Rec. Nat. Prod., 5: 176-183.

Ludlow DI, S Ragone, IS Bruck, JN Bernstein, M Duchowny and BMG Pena, 2004. Neurotoxicities in Infants Seen With the Consumption of Star Anise Tea. Pediatrics, 114: 653-656.

Ma J, X Zeng, K Li, L Deng and K Huang, 2011. Status quo and development strategy of star anise industry in Guangxi. Guangxi For. Sci., 40: 336-339.

Mathon C, B Bongard, M Duret, D Ortelli, P Christen and S Bieri, 2013. Analysis of the neurotoxin anisatin star anise by LC-MS/MS. Food Addit. Contam., 30: 1598-1605.

Mahood RAH, 2012. Effects of Pimpinella anisum oil extract on some biochemical parameters in mice experimentally induced for human polycystic. Journal of Biotechnology Research Center, 6: 67-73.

Mirheydar H, 2001. Herbal Information: Usage of Plants in Prevention and Treatment of Diseases. Islamic Culture Press Center, Tehran, Iran.

Mohamed HSAA, WS Abdelgadir and AZI Almagboul AZI, 2015. In vitro antimicrobial activity of anise seed (Pimpinella anisum L.). Int. J. Adv. Res., 3: 359-367.

Mosaffa-Jahromi M, AM Tamaddon, S Afsharypuor, A Salehi, SH Seradj, M Pasalar, P Jafari and K Bagheri Lankarani, 2017. Effectiveness of anise oil for treatment of mild to moderate depression in patients with irritable bowel syndrome: a randomized active and placebo-controlled clinical trial. Journal of EvidenceBased Complementary and Alternative Medicine, 22: 41-46.

Mukhia PB, 2006. Management guidelines for Illicium griffithii for Community Forests of Bhutan, SFD, Thimphu, Bhutan.

Nahidi F, N Kariman, M Simbar and F Mojab, 2012. The study on the effects of Pimpinella anisum on relief and recurrence of menopausal hot flashes. Iran. J. Pharm. Res., 11: 1079-1085.

Nakazawa Y, F Takenaka, K Sakai, Y Matsunaga, T Oka, S Sadamatsu and S Kono, 1959. On the isolation of an active principle from Illicium anisatum L., its content and toxicity. Folia Pharmacologica Japonica, 55: 524-530 (in Japanese)

National Committee for clinical Laboratory Standards: Performance Standards for Antimicrobical Susceptibility Testing. Twelfth Informational Supplement. Publication M100-S12. National Committee of Clinical Laboratory Standards, Wayne, PA.

Nikfarjam M, M Bahmani and S Heidari-Soureshjani, 2016. Phytotherapy for anxiety in Iran: A review of the most important anti-anxiety medicinal plants. Journal of Chemical and Pharmaceutical Sciences, 9: 12351241.

Niksokhan M, N Hedarieh, M Najafifard and M Najafifard, 2015. Effect of hydro-alcoholic extract of Pimpinella anisum seed on anxiety in male rat. Journal of Gorgan University of Medical Sciences, 16: 28-33.

Ogbaji PO, MH Shahrajabian and X Xue, 2013. Changes in germination and primarily growth of three cultivars of tomato under diatomie and soil materials in auto-irrigation system. International Journal of Biology, 5: 80.

Obaji PO, J Li, X Xue, MH Shahrajabian and E Egrinya, 2018. Impact of bio-fertilizer or nutrient on Spniach (Spinacea Oleracea) growth and yield in some province soils of P.R. China. Cercetari Agronomics in Moldova, 2: 43-52.

Ohira H, N Torii, TM Aida, M Watanabe and RLJ Smith, 2009. Rapid separation of shikimic acid from Chinese star anise (Illicum verum Hook. f.) with hot water extraction. Separation Purification Technology, 69: 102108.

Ooi TL, NC Ying, HI Kilfi and YM Chako, 1994. Palm oil-based printing ink. Palm Oil Developments, 15: 73 74.

Ozel A, 2009. Anise (Pimpinella anisum): changes in yields and component composition on harvesting at different stages of plant maturity. Exp. Agr., 45: 117-126.

Ozkan MM and JC Chalchat, 2006. Chemical composition and antifungal effect of anise (Pimpinella anisum L.) fruit oil at ripening stage. Ann. Microbiol., 56: 353-358. 
Parasa LS, SR Tumati, CS Prasad and LCA Kumar, 2012. In vitro antibacterial activity of culinary spices aniseed, star anise and cinnamon against bacterial pathogens of fish. Int. J. Pharm. Pharm. Sci., 4: 667-670.

Paul A, J Kalita, ML Khan and OM Tripahti, 2013. Illicium griffithii Hook. f. \& Thoms.- A potential source of natural off-farm income to the rural people of Arunachal Himalaya. Indian Journal of Natural Products and Resources, 4: 131-137.

Pavela R, 2014. Insecticidal properties of Pimpinella anisum essential oils against the Cluex quinquefasciatus and the non-target organism Daphnia magna. J. Asia-Pac. Entomol., 17: 287-293.

Peng W, Z Lin, L Wang, J Chang, F Gu and X Zhu, 2016. Molecular characteristics of Illicium verum extractives to activate acquired immune response. Saudi J. Biol. Sci., 23: 348-352.

Picon PD, RV Picon, AF Costa, GB Sander, KM Amaral, AL Aboy and AT Henriques, 2010. Randomized clinical trial of a phytotherapic compound containing Pimpinella anisum, Foeniculum vulgare, Sambucus nigra, and Cassia augustifolia for chronic constipation. BMC Complem. Altern. M., 10: 17.

Park SH, YY Sung, KJ Nho and HK Kim, 2015. Protective activity ethanol extract of the fruits of Illicium verum against atherogenesis in apolipoprotein E knockout mice. BMC Complem. Altern. M., 15: 232.

Prajapati ND, SS Purohit, AK Sharmar and T Kumar, 2007. Handbook of complete medicinal plants. Jodhpur (India): Angrobios.

Prakash B, Shukla R, Singh P, Mishra PK, Dubey NK, Kharwar RN. 2011. Efficacy of chemically characterized Ocimum gratissmum $L$. essential oil as antioxidant and a safe plant based antimicrobial against fungal and aflatoxin B1 contamination of spices. Food Res. Int., 44: 385-390.

Qin W, Lin J, Qibiao W. 2007. Effect of three extraction methods on the volatile component of Illicum verum Hook. $f$. analyzed by GC-MS. Wuhan University Journal of Natural Sciences, 12: 529-534.

Radaelli M, Silva BPD, Weidlich L, Hoehne L, Flach A, Costa LAMAD, Ethur EM. 2016. Antimicrobial activities of six essential oils common used as condiments in Brazil against clostridium perfringens. Braz. J. Microbiol., 47: 424-430.

Rapisarda A. 2004. Economic importance and market trends of the genera Pimpinella, Illcium and Foeniculum. (Ed.): M. Jodral. Illicum and Foeniculum Boca Raton: CRC Press, pp. 191-218.

Rattan S, Satpathy G, Gupta RK. 2014. Formulation of biscuits with Glycyrrhiza glabra root extract, Ocimum sanctum and Pimpinella anisum extract added as nutraceutical. J. Pharmacogn. Phytochem., 3:10-16.

Ringman M, Frautschy A, Cole M, Masterman L, Cummings L. 2005. Potential role of the curry spice curcumin in Alzheimer's disease. Curr. Alzheimer Res., 2:131-136.

Ritter AMV, Ames FQ, Otani F, de Oliveria RMW, Cuman RKN, Bersani-Amado CA. 2014. Effects of anethole in Nociception experimental models. Hindawi Publishing Corporation, Evidence-Based Complementary and Alternative Medicine. Article ID 345829, 7 pages.

Romanov MS, AVFC Bobrov and PK Endress, 2013. Structure of the usual explosive fruits of the early diverging angiosperm Illicium (Schisandraceae s.l., Austrobaileyales). Botanical Journal of the Linnean Society, 171: 640-654.

Ross IA, 2001. Medicinal Plants of the World. Vol. 2: Chemical Constituents, Traditional and Modern Uses Humana Press Inc. New Jersey.

Scharge M, Y Shen, FW Claassen, H Zuilhof, MWF Nielen, B Chen and TA van Beek, 2013. Rapid and simple neurotoxin-based distinction of Chinese and Japanese star anise by direct plant spray mass spectrometry. J. Chromatogr., 1317: 246-253.

Shahamat Z, S Abbasi-Maleki and S Mohammadi Motamed, 2015. Evaluation of antidepressant-like effects of aqueous and ethanolic extracts of Pimpinella anisum L. fruit in mice. Avicenna J. Phytomed., 6: 322-328.

Shahrajabian MH, A Soleymani, PO Ogbaji and X Xue, 2017. Impact of different irrigation managements on soil water consumption, grain yield, seed protein, phosphorus and potassium of winter wheat. Cercetari Agronomice in Moldova, 3: 5-13.

Shahrajabian MH, W Sun and Q Cheng, 2018. A review of goji berry (Lycium barbarum) in traditional Chinese medicine as a promising organic superfood and superfruit in modern industry. Academia Journal of Medicinal Plants, 6: 437-445.

Shahrajabian MH, W Sun and Q Cheng, 2019a. The power of natural Chinese medicine, ginger and ginseng root in an organic life. Middle East J. Sci. Res., 27: 64-71.

Shahrajabian MH, W Sun and Q Cheng, 2019b. Clinical aspects and health benefits of ginger (Zingiber officinale) in both traditional Chinese medicine and modern industry. Acta Agriculturae Scandinavica, Section B- Soil \& Plant Science, 1-11.

Shahrajabian MH, W Sun and Q Cheng, 2019c. Traditional Chinese medicine and agriculture; organic life and sustainability for future. GSC Biological and Pharmaceutical Sciences, 7: 091-095. 
Shahrajabian MH, W Sun and Q Cheng, 2019d. A review of ginseng species in different regions as a multipurpose herb in traditional Chinese medicine, modern herbology and pharmacological science. J. Med. Plants Res., 13: 213-226.

Shahrajabian MH, W Sun and Q Cheng, 2019e. Modern pharmacological actions of Longan fruits and their usages in traditional herbal remedies. J. Med. Plants. Stud., 7: 179-185.

Shahrajabian MH, M Khoshkharam, P Zandi, W Sun and Q Cheng, 2019f. Jujube a super-fruit in traditional Chinese medicine, heading for modern pharmacological science. J. Med. Plants. Stud., 7: 173-178.

Sharifi R, H Kiani, M Farzaneh and M Ahmadzadeh M, 2008. Chemical composition of essential oils of Iranian Pimpinella anisum L. and Foeniculum vulgare Miller and their antifungal activity against postharvest pathogens. Journal of Essential Oil-Bearing Plant (JEOP), 11: 514-522.

Shen Y, TA van Beek, FW Claassen, H Zuilhof, B Chen and MWF Nielen, 2012. Rapid control of Chinese star anise fruits and teas for neurotoxic anisatin by direct analysis in real time high resolution mass spectrometry. J. Chromatogr., 1259: 179-186.

Shirzadi D, S Abbasi-Maleki and A Zanbouri, 2017. Ethanolic extract of anise (Pimpinella anisum L.) attenuates morphine physical dependence in mice. J Herbmed Pharmacol., 6: 69-73.

Shobha RI, CY Rajeshwari and C Andallu, 2013. Anti-peroxidative and anti-diabetic activities of aniseeds (Pimpinella anisum L.) and identification of bioactive compounds. American Journal of Phytomedicine and Clinical Therapeutics, 1: 516-527.

Shojaii A and M Abdollahi Fard, 2012. Review of pharmacological properties and chemical constituents of Pimpinella anisum. ISRN Pharmaceutics. Article ID 510795, 8 pages.

Shu X, XM Liu, CL Fu and QX Liang, 2010. Extraction, characterization and antitumor effect of the polysaccharides from star anise Illicium verum (Hook f). J. Med. Plants Res., 4: 2666-2673.

Sirisha KB and P Sujathamma, 2018. In vitro propagation of few Pimpinella species, a review. Research Journal of Life Sciences, Bioinformatics, Pharmaceutical and Chemical Sciences, 4: 337-344.

Soleymani A and MH Shahrajabian, 2012a. Effects of different levels of nitrogen on yield and nitrate content of four spring onion genotypes. Int. J. Agric. Crop Sci., 4: 179-182.

Soleymani A and MH Shahrajabian, 2012b. Response of different cultivars of fennel (Foeniculum vulgare) to irrigation and planting dates in Isfahan, Iran. Res. Crop., 13: 656-660.

Soleymani A, MH Shahrajabian and L Naranjani, 2013. Effect of planting dates and different levels of nitrogen on seed yield and yield components of nuts sunflower (Helianthus annuus L.). Afr. J. Agric. Res., 8: 58025805 .

Soleymani A and MH Shahrajabian, 2018. Changes in germination and seedling growth of different cultivars of cumin to drought stress. Cercetari Agronomics in Moldova, 1: 91-100.

Sri PU, V Leelavathi, NV Sree and MA Kumar, 2015. Antihelmenthic and antimicrobial activity of green synthesized silver nanoparticles from Illicium Verum Hook. F. fruit. IOSR Journal of Pharmacy and Biological Sciences, 10: 61-65.

Sripongpun G, 2008. Contact toxicity of the crude extract of Chinese star anise fruits to house fly larvae and their development. Songklanakarin Journal of Science and Technology, 30: 667-672.

Stojanovic T, V Butsic, G Vukovic, J Sucur, A Popovic, M Zmijanac, B Kuzmanovic and A Petrovic. 2018. The chromatographic analysis of the star anise essential oil as the potential biopesticide. Journal of Agronomy, Technology and Engineering Management, 1: 65-70.

Sung YY, YS Kim and HK Kim, 2012. Illicium verum inhibits TNF-a and IFN-g-induced expression of chemokines and cytokines in human Kerationocytes. J. Ethnopharmacol., 144: 182-189.

Techen N, Z Pan, BE Scheffler and IA Khan, 2009. Detection of Illicum anisatum as adulterant of Illicum verum. Planta Medica, 75: 392-395.

Thuat BQ and BTB Ngoc, 2010. Obtaining essential oil and shikimic acid from star anise fruit (Illicium verum Hook). VNU Journal of Science, Natural Sciences and Technology, 26: 110-113.

Tuncturk M and B Yildirim, 2006. Effect of seed rates on yield and yield components of anise (Pimpinela anisum). Indian J. Agric. Sci., 76: 679-681.

Ullah H, A Mahmood and B Honermeier, 2013. Effects of different fungicides on the infection by Passalora malkoffii with respect to the fruit yield and quality of aniseed (Pimpinella anisum L.) in Germany. Journal of Medicinal and Spice Plants, 18: 89-98.

Ullah H, A Mahmmod and B Honermeier, 2014. Essential oil and composition of anise (Pimpinella Anisum L.) with varying seed rates and row spacing. Pak. J. Bot., 46: 1859-1864. 
Uysal H, AA Kara, OF Algur, R Dumlupinar and M Nuri Aydogan, 2007. Recovering effects of aqueous extracts of some selected medical plants on the tetratogenic effects during development of D. melanogaster. Pak. J. Biol. Sci., 10: 1708-1712.

Vecchio MG, A Gulati, C Minto and G Lorenzoni, 2016. Pimpinella Anisum and Illicum Verum: the multifaceted role of anise plants. The Open Agriculture Journal, 10: 81-86.

Verghese J, 1988. The world of spices and herbs. Spice India, 11: 15-18.

Vermaak I, A Viljoen and SW Lindstrom, 2013. Hyperspectral imaging in the quality control of herbal medicines- The case of neurotoxic Japanese star anise. J. Pharmaceut. Biomed., 75: 207-213.

Wang GW, WT Hu, BK Huang and LP Qin, 2011. Illicium verum: a review on its botany, traditional use, chemistry and pharmacology. J. Ethnopharmacol., 136: 10-20.

Wei L, R Hua, M Li, Y Huang, S Li, Y He and Z Shen, 2014. Chemical composition and biological activity of star anise Illicium verum extracts against maize weevil, Sitophilus zeamais adults. J. Insect Sci., 14: 1-13.

Womeni HM, FT Djikeng, B Tiencheu and M Linder, 2013. Antioxidant potential of methanolic extracts and powders of some Cameroonian spices during accelerated storage of soybean oil. Adv. Biol. Chem., 3: 304313.

Yadav AS and D Bhatnagar, 2007. Chemo-preventive effects of star anise in N-nitrosodiethylamine initiated and Phenobarbital promoted hepato-carcinogenesis. Chemico-Biological Interactions, 169: 207-214.

Yamini Y, N Bahramifar, F Sefidkon, MJ Saharkhiz and E Salamifar, 2008. Extraction of essential oil from Pimpinella anisum using supercritical carbon dioxide and comparison with hydrodistillation. Nat. Prod. Res., 22: 212-218.

Yan JH, XX Xiao and KL Huang, 2002. Component analysis of volatile oil from Illicium Verum Hook. $f$. Journal of Central South University of Technology, 9: 173-176.

Yang JF, CH Yang, HW Chang, CS Yang, SM Wang, MC Hsieh and LY Chuang, 2010. Chemical composition and antibacterial activities of Illicium verum against antibiotic-resistant pathogens. J. Med. Food, 13: 12541262.

Yong Y, Y Hu, MH Shahrajabian, C Ren, L Guo, C Wang and Z Zeng, 2017. Organic matter, protein percentage, yield, competition and economics of oat-soybean and oat-ground nut intercropping systems in Northern China. Cercetari Agronomice in Moldova, 3: 25-35.

Yoshikawa T, T Masaki, M Motooka, D Hino and K Ueda, 2018. Highly toxic seeds of the Japanese star anise (llicium anisatum) are the dispersed by a seed-caching bird and a rodent. Ecol. Res., 33: 495-504.

Zand A, MT Darzi and MR Haj Seyed Hadi, 2012. Effects of phosphate solubilizing microoranism and plant density on seed yield and essential oil content of anise (Pimpinella anisum). Middle East J. Sci. Res., 14: 940-946.

Zhang W, Y Zhang, X Yuan and E Sun, 2015. Determination of volatile compounds of Illicum verum Hook. f. using simultaneous distillation-extraction and solid phase microextraction coupled with gad chromatographymass spectrometry. Trop. J. Pharm. Res., 14: 1879-1884.

Zhou X, M Qiu, D Zhao, F Lu and Y Ding, 2016. Inhibitory effects of spices on biogenic amine accumulation during fish sauce fermentation. J. Food Sci., 81: M913- M920.

Zhou BG, S Wang, TT Dou, S Liu, MY Li, RM Hua, SG Li and HF Lin, 2016. Aphicidal activity of Illium verum fruit extracts and their effects on the acetylcholinesterase and glutathione S-transferases activities in Myzus persicae (Hemiptera: Aphididae). J. Insect Sci., 16: 1-7. 